Article

\title{
Health-Oriented Tourists and Sustainable Domestic Tourism
}

\author{
Timothy J. Lee ${ }^{1}$, Ji-Sook Han ${ }^{2}$ and Tae-Gyou Ko ${ }^{3, *}$ \\ 1 Sustainability Research Centre, School of Social Sciences, University of the Sunshine Coast, \\ Maroochydore DC Queensland 4558, Australia; tlee2@usc.edu.au \\ 2 Navi Wellness Tourism Research \& Development, Saechang-ro, Mapo-gu, Seoul 04168, Korea; \\ zen830@naver.com \\ 3 Department of Business Management, College of Business, Hallym University, Chuncheon 24252, Korea \\ * Correspondence: tgko@hallym.ac.kr; Tel.: +82-332-481-846
}

Received: 29 April 2020; Accepted: 1 June 2020; Published: 18 June 2020

\begin{abstract}
Health-oriented tourism has emerged as one of the fastest-growing niche tourism fields worldwide. Although there have been studies on the relationship between health and travel behavior, most have been from the perspective of travel motivation and have rarely examined the impact of travel on health. This study explores those travel elements that have a positive influence on health in the domestic health tourism industry, with health being viewed across three domains: psychological, physical, and social. A total of 28 health-contributing travel items reported by 862 package tour participants were analyzed. On the psychological health dimension, experiencing good feelings and escaping bad ones is important. On the physical wellness dimension, natural patterns of food intake during the day is strongly recognized, including the results of increased appetite and improved digestion. On the social health dimension, relationship improvements were experienced, along with a greater understanding of partner(s). These findings add to our understanding of traveler wellness, a significant step towards having the right information to enhance the quality of travel services, especially in the domestic health tourism industry.
\end{abstract}

Keywords: health-oriented tourism; travel elements; sustainable health; package tourists; domestic tourism; wellness tourism

\section{Introduction}

This study explores the travel elements that contribute to improving the health of domestic tourists by examining the experience of two one-day tours inside Korea [1,2]. It lays the groundwork for further contributions to the theoretical development of the health tourism field and presents factors affecting the health contribution of this form of tourism that have not been discussed so far in the scientific literature [3]. In addition, the study contributes to the identification of what types of health products might be attractive to health tourists, especially in domestic health-related tourism. Travel for health reasons is one of the fastest growing forms of international and domestic tourism, and this growth is predicted to continue [2,4-7]. Global aging is thought to be one of the rationales behind this pattern $[8,9]$. In the South Korean context, the Government wishes to foster the expansion of this new tourism sector to provide services and products for the pursuit of the health and wellness experience [10,11]. In South Korea (hereafter Korea), various areas and themes, such as forests, hot springs, water and herbal baths, are being strategically developed to produce health travel experiences [12,13]; however, the influence of travel on health has not as yet been systematically explored, and the elements and factors that contribute to improve outcomes have not thus been fully identified in the literature. Previous studies have, however, demonstrated the positive impact of travel on psychological wellness [2,6,14-16], perceived physical health [17-19], and mental, physical, and spiritual health [3,8,20-22]. 
In terms of psychological health, Gilbert and Abdullah [16] showed that travel, specifically vacation expectations and vacation experiences, has a positive impact on an individual's subjective wellness, and Han et al. (2018) argues that travel experiences have a positive impact on psychological wellness. Lim, Kim, and Lee [2] found that more frequent travel activities in a wellness tourism destination brought tourists more psychological wellness. Hieda [20] agrees that this outcome of travel is significant but sees the need to provide psychological support for medical and health tourists in their search for treatment and rehabilitation. The study by McCabe and Johnson [6] explored social wellness in a social tourism context and demonstrated how holidays for socially disadvantaged groups produced improvements in aspects of wellness. This confirms the results of other studies that have found that tourism contributes to improvements in the quality of life of travelers [1,23,24].

Orsega-Smith, Mowen, Payne, and Godbey [19] examined the relationships among stress, park visits, and the physical health of older people, showing that socializing in a park has a direct positive impact on physical health, and that a long stay in the park resulted in improved health variables such as lowered blood pressure. Similarly, Han and colleagues [2] showed that among the possible leisure activities undertaken to alleviate negative moods, outdoor activities and travel have the most positive impact on mental health and perceived physical health. Recently, it has also been suggested that an increased number of annual travel days leads to improved mental and physical health [12,25]. The COVID19 pandemic affirms to the world the importance of travel activities. This is true for all people, not only for necessary business purposes but also to fulfil the natural desire of people to temporarily escape or leave an ordinary place to remove daily stress and refresh their mindset so that they can recharge themselves for an energetic and productive lifestyle. This paper is timely and insightful as it emphasizes the contribution to mental health people can expect and enjoy from travel activities and how travel restrictions such as those in place around the world at the time of writing may be as much counterproductive to health as the virus itself.

Regarding the general field of health tourism, most research has focused on the motivational elements for market segmentation $[7,13,18,26,27]$, and the travel elements that contribute to human health remain little researched [20]. However, travel experiences can contribute to the enhancement of health in various ways including physical, intellectual, social, and spiritual wellness $[17,21,28]$. In addition to this marketing orientation, contemporary health tourism studies have predominantly concentrated on international tourists and have been mainly focused on attracting inbound tourists to destinations that offer health tourism products and services [18,29-31].

Conventional mass tourism is often set against natural resources and landscapes to provide artificial attractions for tourists, but this paper is in favor of maintaining natural resources at their best. The current study is focused on the provision of mental healing experiences for urban residents who lack natural landscapes and room for mental relaxation. Most people in urban areas in South Korea (and in many other countries in East Asia) live in apartment complexes and have stressful 'rat-race' lifestyles in the space of the so called 'concrete jungle'. This paper delivers a significant message and contributes to the sustainable role of travel activities in presenting an environment-friendly format for tourists. By developing this type of sustainable tourism within well-preserved natural resources, tourist enjoyment can also be better maintained thanks to the financial contributions by the participants. Thus, this paper is significant in both the tourism and environment perspectives by exploring innovative pathways that the tourism industry can pursue for stress-ridden urban people who are eager to have mind-healing experiences from their travel activity. The current study is unique and timely as it contributes to filling the gap in the field of health tourism by investigating tourist motivation from the perspective of mental strengthening and refreshing, which is required by most urban residents who have few opportunities to encounter nature. This type of tourism also contributes to sustainable and long-term development by maximizing the value of natural resources without over-developing or destroying them. The paper is focused on sustainable tourism for those health tourists who are interested in refreshing their mind and spirit by undertaking travel activities that do not mean the 
massive destruction of natural resources, the construction of dense building forms, or the building of extra infrastructure.

\section{Literature Review}

\subsection{Definition of Health: Psychological, Physical, and Social Domains}

Over the years, the concept of health has changed [32,33]. In the 20th century, in many industrialized countries, deaths caused by infectious diseases (such as influenza, pneumonia, diphtheria) fell sharply. The leading causes of death in recent decades are 'non-communicable diseases' such as heart disease and cancer, and these are mainly caused by bad habits or inappropriate lifestyle choices [32]. Stress, smoking, poor diets, lack of exercise, and heavy alcohol consumption are now the major causes of death [34]. In the 19th and 20th centuries, the biomedical health model, which was confined to describing physical conditions, was not able to explain psychogenic disorders such as stress or the impact of these on general health. More recently, however, the modern definition of health has begun to encompass a person's mental, physical, and social health [15], and further, the World Health Organization (WHO) has introduced spiritual wellness into health domains $[33,35]$. In the modern era, these psychological, physical, and social components are widely-accepted in the definition of health, and also in the concept of wellness, which represents the optimal state of health, resulting in a more positive definition of health $[3,36]$.

Physical health relates to being physically fit, having physical strength, and not injuring oneself during exercise or other activities. Psychological health is related to happiness, confidence, value or purpose in life, and having a positive way of thinking [2,20]. Social health includes interpersonal involvement and appropriate assistance to family and friends [37,38]. Some researchers have further classified psychological health into emotional and intellectual domains, but this study follows the main three domains of health (Table 1). The number of health indicators in the three major areas of psychological, physical, and social health has grown steadily $[6,39,40]$ (Table 2).

Table 1. Three common domains of health: psychological, physical, and social.

\begin{tabular}{ll}
\hline & \multicolumn{1}{c}{ Element } \\
\hline (a) $\begin{array}{l}\text { Optimism, confidence and self-esteem, } \\
\text { self-acceptance, having self-control skills. } \\
\text { (b) } \begin{array}{l}\text { Stress control, ability to express emotions } \\
\text { appropriately and comfortably. }\end{array} \\
\text { Psychological health }\end{array}$ & (c) $\begin{array}{l}\text { Euphoria, confidence, positive thinking } \\
\text { about the value or purpose of one's self. } \\
\text { Ability to recognize and accept external } \\
\text { environment and conditions. } \\
\text { Problem-solving skills to grow up without } \\
\text { failure and frustration, } \\
\text { self-regulation ability. } \\
\text { Degree of positive feelings and passion } \\
\text { about personal life. }\end{array}$ \\
& (d) \\
& (f)
\end{tabular}


Table 1. Cont.

\begin{tabular}{ll}
\hline & \multicolumn{1}{c}{ Element } \\
\hline (a) $\begin{array}{l}\text { Functional ability of the physical body that } \\
\text { can perform routine tasks and duties. }\end{array}$ \\
(b) $\begin{array}{l}\text { Sensitivity, susceptibility to disease and } \\
\text { disability, degree of functions of the body, } \\
\text { capability for recovering. }\end{array}$ \\
(c) Physical condition with the ability to \\
perform work or daily \\
physical development. \\
(d)
\end{tabular}

Source: The authors (2020), adapted from Moon \& Choi (43), and Naidoo \& Wills (44).

Table 2. Psychological, physical and social health measures by chronological order.

\begin{tabular}{|c|c|c|}
\hline & Measuring point & Scale \\
\hline \multirow{4}{*}{$\begin{array}{l}\text { Psycho-logical } \\
\text { health }\end{array}$} & $\begin{array}{l}\text { Good mood (excitement, interested, } \\
\text { calm, contentment, happiness, the } \\
\text { experience of the best), or not feeling } \\
\text { bad (boredom, not happy, soreness, } \\
\text { loneliness, restlessness). }\end{array}$ & $\begin{array}{l}\text { The Affect Balance Scale [41], The Philadelphia } \\
\text { Geriatric Center Morale Scale [42], The } \\
\text { General Health Questionnaire [43], The } \\
\text { General Well-Being Schedule [44], The Rand } \\
\text { Mental Health Inventory [45], Oxford } \\
\text { Happiness Questionnaire [39], The Mental } \\
\text { Health Continuum-Short Form (MHC-SF) [46]. }\end{array}$ \\
\hline & $\begin{array}{l}\text { Life satisfaction, satisfaction with } \\
\text { every lived day, and current status. }\end{array}$ & $\begin{array}{l}\text { The Philadelphia Geriatric Center Morale } \\
\text { Scale [42], The General Health Questionnaire } \\
\text { [43], The Rand Mental Health Inventory [45], } \\
\text { Psychological Well-Being Scale [47], Oxford } \\
\text { Happiness Questionnaire [39]. }\end{array}$ \\
\hline & $\begin{array}{l}\text { Self-control (stress management skills, } \\
\text { emotion regulation skills, thoughts, } \\
\text { feelings, feelings of control). }\end{array}$ & $\begin{array}{l}\text { The General Health Questionnaire [43], The } \\
\text { General Well-Being Schedule [44], The Rand } \\
\text { Mental Health Inventory [45], Psychological } \\
\text { Well-Being Scale [47], Oxford Happiness } \\
\text { Questionnaire [39]. }\end{array}$ \\
\hline & Confidence, belief in self, self-esteem. & $\begin{array}{l}\text { The General Health Questionnaire [43], } \\
\text { Psychological Well-Being Scale [47], Oxford } \\
\text { Happiness Questionnaire [39]. }\end{array}$ \\
\hline
\end{tabular}


Table 2. Cont.

\begin{tabular}{lll}
\hline & \multicolumn{1}{c}{ Measuring point } & \multicolumn{1}{c}{ Scale } \\
\hline \multirow{3}{*}{ Physical health } & $\begin{array}{l}\text { Appetite, gastrointestinal functioning, } \\
\text { quality of sleeps, fatigue, cold sweat. }\end{array}$ & $\begin{array}{l}\text { Health Opinion Survey [48], The SF-36 Health } \\
\text { Measures [49]. }\end{array}$ \\
\cline { 2 - 3 } & Activities, body movement. & $\begin{array}{l}\text { The Functional Activities Questionnaire [50], } \\
\text { The SF-36 Health Measures [49]. }\end{array}$ \\
\cline { 2 - 3 } & Activities and energy. & $\begin{array}{l}\text { The General Well-Being Schedule [44], The } \\
\text { SF-36 Health Measures [49]. }\end{array}$ \\
\cline { 2 - 3 } & $\begin{array}{l}\text { Healthy feeling. } \\
\text { Social support: having person(s) who } \\
\text { talk to each other and are happy to be } \\
\text { with others. }\end{array}$ & $\begin{array}{l}\text { The Social Support Questionnaire [51], } \\
\text { Multidimensional Scale of Social Support [52]. }\end{array}$ \\
\hline & $\begin{array}{l}\text { The Social Relationship Scale [53], The Family } \\
\text { Relationship Index [54], Multidimensional } \\
\text { Scale of Social Support [52], Psychological } \\
\text { Intimacy, trust, respect, and } \\
\text { self-expression in social relationships. }\end{array}$ \\
& $\begin{array}{l}\text { Well-Being Scale [47], Oxford Happiness } \\
\text { Questionnaire [39]. }\end{array}$ \\
\cline { 2 - 3 } & $\begin{array}{l}\text { Intimacy and exchange with family, } \\
\text { neighbors, and participation in } \\
\text { group activities. }\end{array}$ & \begin{tabular}{l} 
Multidimensional Scale of Social Support [52]. \\
\hline
\end{tabular}
\end{tabular}

Source: The authors (2020).

\subsection{The Impacts of Travel on Health}

An early study by Finnicum and Zeiger [28] showed that travelling in nature has a close relationship with wellness, providing the hypothesis that outdoor activities can have a positive impact on physical, intellectual, social, and spiritual health. Their study was conducted in Arkansas, in the Southern United States, and the authors showed that the travelers had the chance to enhance their health in various ways within beautiful natural surroundings, while tourism could provide the necessary opportunities for this to happen. For example, in the physical domain, people can stop their feelings of fatigue through walking and hiking, and these physical activities enhance their endurance and flexibility, although the latter mainly applies to relatively younger people [55]. In addition, enjoying spa and outdoor activities helps people to relax. In the intellectual realm, travel provides opportunities for the stimulation of the human intellect via direct experience, and this can expand the cognitive domain of the individual. Finally, regarding the social health domain, the focus is on the formation of creative, healthy, and/or steady relationships with people via positive exchanges with others, and this is possible within the framework of the variety of recreational opportunities available during travel [6].

Wellness Tourism Worldwide [36] claims that people travel with the explicit aim or principal motivation of improving their physical and mental wellbeing, and this can include stress reduction and calming of the mind, as well as healing or rejuvenating the body. The anticipation and planning of travel, enjoying a vacation, and relishing the memories that often last a lifetime, have been shown to be happiness-enhancing elements of a tour, and it has also been suggested that tourism can improve health by enhancing sleep, and remarkably, decreasing the incidence of heart disease [3]. However, what are the specified travel elements that explain the enhancement of health? Previous research is not clear in this regard, because it should also be remembered that travel may also induce stress [20]. Jo [56] indicates that little research has been done regarding the stress tourists experience from traveling overseas. Jo's [56] study suggested that long flights, cross-cultural adaptation, shopping and inappropriate leadership during travel can cause travel stress. The current study examined only the positive aspect of travel although travel itself can also have negative impact on traveler health. 


\subsection{Health and Wellness Tourism}

It appears that as far back as before Roman times, people traveled for 'the cure' to hot springs [9,15], as did the Chinese, Koreans and Japanese [15] in East Asia. In Europe between the 15th and 17th centuries, unsanitary living conditions motivated tours by the rich to upscale treatment spas and mineral springs [57]. More recently, the motivations of health and/or wellness tourists have been well researched, and the data organized in terms of different products, markets, or specified destinations [58]. Wellness tourists are believed to be motivated to optimize their physical and mental health, and depending on their personal circumstances, they may be seeking to escape from stress; rest and relaxation; a spiritual experience; to be in nature; self-development or improvement; to meet like-minded people and form communities; and emotional or creative expression $[7,8,26,59]$.

Voigt et al. [27], using semi-structured interviews, investigated the experiences of 27 wellness tourists who had visited beauty spas, lifestyle resorts, and spiritual retreats, and six benefit factors emerged from the principal axis factor analysis used in that study: transcendence; physical health and appearance; escape and relaxation; important others and novelty; re-establishing self-esteem; and indulgence. Further investigation with 509 wellness tourists found that of the six benefit factors, one, physical health and appearance, was significantly more important to lifestyle resort visitors compared to the other two groups (beauty spas and spiritual retreats). The benefit factors of indulgence, and important others and novelty were, therefore, more significant for beauty spa visitors than the other two groups. The factors of re-establishing self-esteem and overcoming major negative life events were also important. Laesser [30] analyzed 11,000 tours taken in Switzerland, and found that the rewarding elements of beauty, indulgence, and regeneration were seen as health tourism motivations. These results can be useful for market analysis; however, again they do not explain which travel elements contribute to health domains. Once these elements are identified, appropriate health travel products can be developed.

In determining directions and strategies for health and wellness tourism products and destination development, the focus has largely been on regional development and site management, rather than on the effectiveness of the programs in terms of health benefits [59]. Moreover, the effectiveness of health tourism has been mainly described in economic terms (employment, economy, living conditions), socio-cultural impacts (cultural heritage, populations, community), and environmental impacts (vegetation and wildlife, land use) [31]. The effectiveness of specific health tourism activities such as yoga, sports and fitness, beauty treatment, and so on, have been examined, but there is a lack of analysis of general health factors that could be obtained through a variety of experiential activities in the travel realm [9]. Moreover, there has been little effort to date to classify the travel health effect in the overall area of human health, which is not helpful in guiding health and wellness tourism product development. Moreover, many travelers themselves remain unaware of the positive health effects of those activities that influence user choice in terms of the travel product.

To contribute to the closure of this gap in our knowledge, the current study investigated the health-enhancing elements of travel activities based on domestic tourism package programs in Korea. It provides information on the psychological, physical, and social components of health, and analyses the positive impacts that tourism and travel activities have on these. Further, it presents a case study based on the relationships between tourism activities and health, especially in the domestic tourism industry, whereas most studies in these fields are mainly on the international tourism industry.

\section{Methodology}

Korea has 51 million people, with nearly half living within $100 \mathrm{~km}$ of Seoul, the capital city. Gangneung City is located about $250 \mathrm{~km}$ from Seoul, $2.5 \mathrm{~h}$ by car. It is one of the major cities of the east coast, with 220,000 people, and one of the major tourist destinations in Gangwon Province, where it is well-known for its beautiful mountains and clean beaches. Moreover, the city is often used as a symbol of rest, recreation, and wellness, and for holidays that offer natural healing for both the body and soul of travelers who are tired of their urban, stressed, and busy daily life. Gangneung City 
generally enjoys milder winters and relatively cooler summers than the rest of Korea, and it has well-preserved traditions, historical relics, and extensive tourist services. The city promotes special health and wellness tourism products using the resources of its wonderful natural environment, along with its art, traditional festivals, organic food, and meditation [60].

\subsection{The Survey Process}

The survey for this study was conducted in Gangneung City by the authors and three tour operators from a private travel agency. The survey respondents were randomly selected from those who took a one-day package tour program named the 'Health \& Wellness Tour', which was organized by a major travel agency and the quasi-public organization of Gangneung City. A small gift was given to the respondents who completed the questionnaire as a token of appreciation. The survey was carried out every Tuesday, Saturday, and Sunday, for 12 days in total in the winter season. Towards the end of the tour, surveys were distributed on the way back to Seoul and the survey responses were voluntary and remained anonymous. Approximately 75 to 80 responses per day were collected from the chartered tour bus used by each of the Gyeongpo and Jeongdongin package tours. The researchers gained cooperation from the travel agency, and guided questionnaire collection. A total of 918 questionnaires were distributed, and 862 completed responses were used in the analysis.

The tours were held in two areas of Gangneung City: Gyeongpo (abbreviated as GP) and Jeongdongjin (abbreviated as JDJ). These two one-day tours can be described as general tours that include some health-contributing items such as providing natural food, or a walking program in the fresh-air of mountain areas. The GP (famous beach resort destination) itinerary included visiting historical places, experiencing healthy traditional food, a tea ceremony experience, and walking along the beach and in a pine forest. The JDJ (famous for sunrise tourism) itinerary included hiking, healthy vegetarian Buddhist temple food, visiting a local culture exhibition hall, a coffee roasting experience, walking and watching the winter scenery of the East Sea, and so on (Tables 3 and 4).

Table 3. Itinerary of 'Health \& Well-being Tour' in the Gyeongpo (GP) area.

\begin{tabular}{|c|c|}
\hline Time & Schedule \\
\hline 07:00 & Departure from Seoul. \\
\hline 10:30 11:40 & Visit to a historical heritage site where local historic celebrity family lived in the $16^{\text {th }}$ Century. \\
\hline 11:40 13:00 & $\begin{array}{l}\text { Lunch with traditional healthy meal with organic food distinctively provided in the local } \\
\text { Gangneung area. }\end{array}$ \\
\hline 13:00 14:30 & $\begin{array}{l}\text { Therapeutic walk in the pine forest. } \\
\text { Experience of traditional health tea ceremony and learning about etiquette and how to make } \\
\text { the healthy herbal tea. }\end{array}$ \\
\hline 14:30 16:30 & $\begin{array}{l}\text { Coffee tasting (well-known in the Gangneung countrywide) experience and roasting. } \\
\text { Therapeutic walk in the forest along the ocean beach next to black pine forest. } \\
\text { Wishing a happy New Year while enjoying pine forest, and the beach in the East Sea ( } 4 \mathrm{~km} \text { stretch). }\end{array}$ \\
\hline $16: 30$ & Departure from Gangneung to return to Seoul. \\
\hline
\end{tabular}

In this study, the contribution of travel activities, specifically one-day package deals, to health outcomes were investigated, and the contributions are shown for each domain of health-psychological, physical, and social health. The survey used coded check list questions in addition to open-ended questions. The reason for using coded questions is that the respondents did not have much background knowledge about the three domains of health, thus the researchers needed to provide easily related examples including an 'others' item; so that respondents were able to select items which agreed with their travel experience. A space for open questions allowed respondents to write about their travel experiences if they wished. It was also intended that additional open questions would supplement pre-coded questions. The reliability of the scales was confirmed as acceptable with $\alpha=0.911$ for the 
11 items covering psychological health, $\alpha=0.843$ for the nine covering physical health, and $\alpha=0.713$ for the eight covering social health.

Table 4. Itinerary of 'Health \& Well-being Tour' in the Jeongdongjin (JDJ) area.

\begin{tabular}{cc}
\hline Time & Schedule \\
\hline 07:00 & Departure from Seoul. \\
\hline 10:30 12:00 & $\begin{array}{r}\text { Mountain-hike } 300 \mathrm{~m} \text { above sea level, walk passing through natural arboretum. } \\
\text { Wishing a happy New Year watching mountain and the East Sea. }\end{array}$ \\
\hline 12:00 13:00 & Lunch with healthy vegetarian 'Buddhist temple food' (macrobiotic food). \\
\hline 13:00 15:00 & $\begin{array}{c}\text { Visit to local health tourism sites and local culture exhibition hall. } \\
\text { Coffee roasting experience at one of the most famous coffee shops in Korea. }\end{array}$ \\
\hline 15:00 16:30 & Relaxing with a cup of herbal tea while watching the beautiful winter scenery of the East Sea. \\
\hline 16:30 & $\begin{array}{r}\text { Visiting a famous film-induced tourism site in the local area (location of a popular TV drama). } \\
\text { Departure from Gangneung to return to Seoul. }\end{array}$ \\
\hline
\end{tabular}

\subsection{Health-Contributing Items in the Questionnaire}

For the check list questions, travel-related health-contributing items were developed in the three domains of health-psychological, physical, and social health. The questionnaire survey was conducted by research instruments validated by previous studies (Table 2). There were 28 questions: 11 about psychological health, nine about physical health, and eight about social health. These questions were open ended and mainly derived from existing health definitions [37,38]; several health indicators of psychological, physical and social domains were reviewed and used (Table 2). The items were refined by pre-test for securing validity and reliability with seven people: two who work in the health industry and five who do not. Replies were received from 172 people about the psychological impacts, 153 people about the physical impacts, and 110 people about the social impacts from the 862 people who participated in the research. The advantage of open-ended questions is that the respondents' answers are not unduly influenced by the interviewer or by the wording of the questionnaire, and that the replies from respondents can provide a rich source of varied material that might have been hidden by the categories in a pre-coded list [61].

\section{Results}

\subsection{Demographic Characteristics of Participants}

As indicated in Table 5, the participants consisted of $76 \%$ females and $24 \%$ males. Many of the participants were middle aged or elderly, with $42 \%$ being in their 50 s, and $25 \%$ in their 60 s. More than half of the participants (54\%) were travelling with family, and $32 \%$ were with friends. Two-thirds of them came from Seoul, 25\% from Gyeonggi, and 8\% from Incheon.

Table 5. Demographic characteristics of participants.

\begin{tabular}{|c|c|c|c|c|c|c|c|}
\hline & & \multicolumn{2}{|c|}{$\begin{array}{l}\text { GYEONGPO } \\
(\mathrm{GP})(\mathrm{n}=435)\end{array}$} & \multicolumn{2}{|c|}{$\begin{array}{l}\text { Jeongdongjin } \\
\text { (JDJ) }(n=427)\end{array}$} & \multicolumn{2}{|c|}{ Total $(n=862)$} \\
\hline & & Number & Ratio & Number & Ratio & Number & Ratio \\
\hline \multirow{2}{*}{ Gender } & Male & 89 & $20 \%$ & 116 & $27 \%$ & 205 & $24 \%$ \\
\hline & Female & 346 & $80 \%$ & 311 & $73 \%$ & 657 & $76 \%$ \\
\hline
\end{tabular}


Table 5. Cont.

\begin{tabular}{|c|c|c|c|c|c|c|c|}
\hline & & \multicolumn{2}{|c|}{$\begin{array}{l}\text { GYEONGPO } \\
\text { (GP) }(\mathrm{n}=435)\end{array}$} & \multicolumn{2}{|c|}{$\begin{array}{l}\text { Jeongdongjin } \\
(J D J)(n=427)\end{array}$} & \multicolumn{2}{|c|}{ Total $(n=862)$} \\
\hline & & Number & Ratio & Number & Ratio & Number & Ratio \\
\hline \multirow{6}{*}{ Age } & 18 to 20 & 20 & $5 \%$ & 17 & $4 \%$ & 37 & $4 \%$ \\
\hline & 21 to 30 & 21 & $5 \%$ & 24 & $6 \%$ & 45 & $5 \%$ \\
\hline & 31 to 40 & 36 & $8 \%$ & 23 & $5 \%$ & 59 & $7 \%$ \\
\hline & 41 to 50 & 72 & $17 \%$ & 70 & $16 \%$ & 142 & $16 \%$ \\
\hline & 51 to 60 & 183 & $42 \%$ & 177 & $41 \%$ & 360 & $42 \%$ \\
\hline & 61 or older & 103 & $24 \%$ & 116 & $27 \%$ & 219 & $25 \%$ \\
\hline \multirow{5}{*}{ Companion } & Family & 222 & $51 \%$ & 242 & $57 \%$ & 464 & $54 \%$ \\
\hline & Friend & 150 & $34 \%$ & 129 & $30 \%$ & 279 & $32 \%$ \\
\hline & Partner & 12 & $3 \%$ & 14 & $3 \%$ & 26 & $3 \%$ \\
\hline & Colleague & 31 & $7 \%$ & 23 & $5 \%$ & 54 & $6 \%$ \\
\hline & Others & 20 & $5 \%$ & 19 & $4 \%$ & 39 & $5 \%$ \\
\hline \multirow{4}{*}{ Area of residence } & Seoul City & 289 & $66 \%$ & 281 & $66 \%$ & 570 & $66 \%$ \\
\hline & Gyeonggi Province & 102 & $23 \%$ & 115 & $27 \%$ & 217 & $25 \%$ \\
\hline & Incheon City & 41 & $9 \%$ & 28 & $7 \%$ & 69 & $8 \%$ \\
\hline & Others & 3 & $1 \%$ & 3 & $1 \%$ & 6 & $1 \%$ \\
\hline \multirow{6}{*}{ Occupation } & Office worker & 105 & $24 \%$ & 108 & $25 \%$ & 213 & $25 \%$ \\
\hline & Self-employed & 28 & $6 \%$ & 42 & $10 \%$ & 70 & $8 \%$ \\
\hline & Service / Sales & 32 & $7 \%$ & 22 & $5 \%$ & 54 & $6 \%$ \\
\hline & Student & 31 & $7 \%$ & 23 & $5 \%$ & 54 & $6 \%$ \\
\hline & Housewife & 200 & $46 \%$ & 194 & $45 \%$ & 394 & $46 \%$ \\
\hline & Others & 39 & $9 \%$ & 38 & $9 \%$ & 77 & $9 \%$ \\
\hline
\end{tabular}

\subsection{The Frequency of Health-Contributing Travel Items}

In the psychological health dimension, $69 \%$ agreed that they had a 'feeling good' experience, $25 \%$ were persuaded to 'accepting myself as is', $25 \%$ to 'seeing myself in a positive way', $25 \%$ to 'getting out of bad feelings', $20 \%$ to 'gaining the strength to control myself', $19 \%$ to 'regaining confidence', $17 \%$ to 'improving self-esteem', $17 \%$ to 'enhancing self-belief', and 11\% to 'gaining power to solve problems'. In the physical health dimension, $70 \%$ agreed with the concept of 'eating good foods for body such as healthy or macrobiotic food', $47 \%$ with 'feeling natural energy being charged in my body', $44 \%$ with 'awakening the five senses with natural encounters', $43 \%$ with 'making more activities and movement than usual', 40\% with 'feeling healthier while traveling', 26\% with 'increased appetite and better digestion', $20 \%$ with 'relaxing my tense body', and 20\% with 'reflecting on my body and recognizing what is important'. Finally, in the social health dimension, $51 \%$ agreed with the concept of 'improving relationships between people traveling together', 39\% with 'understanding and respecting those who travel together more', $38 \%$ with 'having more opportunities to talk to people traveling together', $30 \%$ with 'deepening trust with people traveling together', $20 \%$ with 'having opportunity to express my new self', $15 \%$ with 'having opportunity to get to know a variety of people', and 15\% with 'expressing myself socially while traveling' (Table 6).

Thus, the open questionnaire results stressed different aspects of travel experience in relation to the health contribution items in the psychological, physical and social domains. 
Table 6. Frequency of contributing travel items in three domains of health.

\begin{tabular}{|c|c|c|c|c|c|c|}
\hline & \multicolumn{2}{|c|}{$\mathrm{GP}^{*}(\mathrm{n}=435)$} & \multicolumn{2}{|c|}{ JDJ $* *(n=427)$} & \multicolumn{2}{|c|}{ Total $(n=862)$} \\
\hline & Number & Ratio & Number & Ratio & Number & Ratio \\
\hline \multicolumn{7}{|l|}{ Psychological health } \\
\hline 1. Experience of good feeling. & 291 & $67 \%$ & 303 & $71 \%$ & 595 & $69 \%$ \\
\hline 2. Accepting myself as I am. & 104 & $24 \%$ & 115 & $27 \%$ & 220 & $25 \%$ \\
\hline 3. Seeing myself in a positive way. & 117 & $27 \%$ & 98 & $23 \%$ & 216 & $25 \%$ \\
\hline 4. Getting out of bad feelings. & 113 & $26 \%$ & 98 & $23 \%$ & 211 & $25 \%$ \\
\hline 5. Gaining the strength to control myself. & 87 & $20 \%$ & 85 & $20 \%$ & 172 & $20 \%$ \\
\hline 6. Regaining confidence. & 74 & $17 \%$ & 90 & $21 \%$ & 164 & $19 \%$ \\
\hline 7. Improving self-esteem. & 74 & $17 \%$ & 77 & $18 \%$ & 151 & $17 \%$ \\
\hline 8. Enhancing self-belief. & 78 & $18 \%$ & 64 & $15 \%$ & 142 & $17 \%$ \\
\hline 9. Thinking that I'm great. & 70 & $16 \%$ & 64 & $15 \%$ & 134 & $16 \%$ \\
\hline 10. Gaining power to solve problems. & 48 & $11 \%$ & 43 & $10 \%$ & 91 & $11 \%$ \\
\hline 11. Others. & 26 & $6 \%$ & 30 & $7 \%$ & 56 & $6 \%$ \\
\hline \multicolumn{7}{|l|}{ Physical health } \\
\hline 1. Eating organic or healthy foods. & 331 & $76 \%$ & 273 & $64 \%$ & 604 & $70 \%$ \\
\hline $\begin{array}{l}\text { 2. Feeling natural energy being charged in } \\
\text { my body. }\end{array}$ & 200 & $46 \%$ & 205 & $48 \%$ & 405 & $47 \%$ \\
\hline $\begin{array}{l}\text { 3. Awakening five senses with natural } \\
\text { encounter. }\end{array}$ & 183 & $42 \%$ & 201 & $47 \%$ & 383 & $44 \%$ \\
\hline 4. Making more activities than usual. & 174 & $40 \%$ & 201 & $47 \%$ & 375 & $43 \%$ \\
\hline 5. Feeling healthier while traveling. & 178 & $41 \%$ & 162 & $38 \%$ & 341 & $40 \%$ \\
\hline 6.Increased appetite and better digestion. & 117 & $27 \%$ & 107 & $25 \%$ & 224 & $26 \%$ \\
\hline 7. Relaxing tense body. & 100 & $23 \%$ & 77 & $18 \%$ & 177 & $21 \%$ \\
\hline $\begin{array}{l}\text { 8. Reflecting my body and recognizing what } \\
\text { is important. }\end{array}$ & 91 & $21 \%$ & 81 & $19 \%$ & 172 & $20 \%$ \\
\hline 9. Others. & 13 & $3 \%$ & 9 & $2 \%$ & 22 & $3 \%$ \\
\hline \multicolumn{7}{|l|}{ Social health } \\
\hline $\begin{array}{l}\text { 1. Improving relationship with people } \\
\text { traveling together. }\end{array}$ & 222 & $51 \%$ & 222 & $52 \%$ & 444 & $51 \%$ \\
\hline $\begin{array}{l}\text { 2. Understanding and respecting those who } \\
\text { travel together more. }\end{array}$ & 170 & $39 \%$ & 162 & $38 \%$ & 332 & $39 \%$ \\
\hline $\begin{array}{l}\text { 3. Having more opportunities to talk to people } \\
\text { traveling together. }\end{array}$ & 170 & $39 \%$ & 158 & $37 \%$ & 328 & $38 \%$ \\
\hline $\begin{array}{l}\text { 4. Deepening trust with people } \\
\text { traveling together. }\end{array}$ & 135 & $31 \%$ & 124 & $29 \%$ & 259 & $30 \%$ \\
\hline $\begin{array}{l}\text { 5. Having the opportunity to express my } \\
\text { new self. }\end{array}$ & 83 & $19 \%$ & 94 & $22 \%$ & 177 & $20 \%$ \\
\hline $\begin{array}{l}\text { 6. Having the opportunity to get to know a } \\
\text { variety of people. }\end{array}$ & 74 & $17 \%$ & 56 & $13 \%$ & 129 & $15 \%$ \\
\hline 7. Expressing myself sociably while traveling. & 48 & $11 \%$ & 34 & $8 \%$ & 82 & $10 \%$ \\
\hline 8. Others. & 13 & $3 \%$ & 21 & $5 \%$ & 34 & $4 \%$ \\
\hline
\end{tabular}

* GP: Gyeongpo; ** JDJ: Jeongdongjin.

\subsection{The Psychological Health-Contributing Travel Experience}

1. Experience a positive mood: More than two-thirds mentioned the feeling of gaining a positive mood from their tour experience. A positive mood was mainly associated with: (a) experiencing nature; (b) gaining a new understanding about history and culture; (c) delicious food; (d) gathering family, friends, and good people together; and (e) the feelings of freedom, joy, and anticipation resulting from travel.

2. Getting out of a negative mood: Most of the respondents answered that they could escape from routine inactive moods such as 'boredom', 'worry', 'heaviness', or 'repetition' by touring. Many people also suggested that they could reduce 'workplace anxiety and stress'. These releasing experiences are associated with nature such as air, sea, waves, wind and other natural resources, and the sense of freedom. 
3. Getting confidence and strength: Participants seemed to gain strength and confidence through being recharged and psychologically recovered through encounters with nature and getting away from their busy daily life.

4. Improving self-esteem: In addition, the participants seemed to find that travel allowed them time for themselves. Travel took them away from complex and busy lives, and they had the chance to look back at themselves and find that they perceived themselves positively. This allowed them to improve their self-esteem.

\subsection{The Physical Health-Contributing Travel Experience}

1. Wellness, food intake and good digestion: There were many positive opinions about the natural food provided for lunch with respect to it helping with physical health. Participants thought that the no-added-chemical seasonings of traditional food, and wild greens and vegetables meant that vegetarian Buddhist temple food helped their physical health; and they said that those foods were well-digested. The GP tour provided traditional pesticide-free organic Korean food and the JDJ tour provided vegetarian temple food (macrobiotic food).

2. Activities that recharge physical energy: There were several positive opinions about increasing activities and recharging physical energy. These were associated with wellbeing-food intake, meeting with nature, and increased body activities through the travel program such as leisurely walking, light climbing, or beach walking.

3. Purification and five senses experience: Some participants mentioned their experience as feelings of clarifying the body and awakening the five senses via facing nature in the sound, air and visual dimensions, and so on. Related experiences were tea ceremony, tea experience, fine forest walking and so on.

4. Reflection about health: Some participants showed reflective ideas with respect to maintaining their physical health, particularly about their normal lack of exercise, and a new awareness concerning food, such as the importance of traditional food and recipes or natural food was also mentioned.

\subsection{Social Health-Contributing Travel Experiences}

1. Relationship improvement: Participants indicated increased intimacy through the time spent with family and friends on the tour, and this helped to strengthen their relationships. There was sufficient time to talk and opportunities to laugh, and some said it was a long enough time to travel with people who are important to them.

2. Social support: There were opinions regarding the social support elements of travel. Participants were happy and comfortable while traveling as they could talk a lot with people who came together. They were in company with people who listened to their stories.

3. Others: For the social health dimension, there were opinions related to understanding others, getting the chance to know other people, and finding one's self in social relationships.

\section{Discussion}

The purpose of this study was to explore those travel elements that have a positive influence on health in the domestic health tourism industry, with health being viewed across three domains: psychological, physical, and social. Although there have been studies on the relationship between health and travel behavior, most have been from the perspective of travel motivation and have rarely examined the results of travel on health. A total of 28 health-contributing travel items were explored in this study and the results suggest that there are several potential positive elements influencing health.

In the psychological health dimension, $69 \%$ of the participants stated that they experienced good feelings during the one-day tour, and $25 \%$ said that the tour helped to lift them out of a bad mood. For health indicators, it is well recognized that experiencing a good mood is an important indicator of psychological wellness, as is experiencing fewer bad feelings. Other positive results included 'accepting myself as is' (25\%), 'seeing myself in a positive way' $(25 \%)$, and 'thinking that I'm 
great' $(16 \%)$. Satisfaction with current status is thus also a significant sign of psychological wellness. Confidence, believing in self and self-esteem are necessary pointers of psychological wellness, as are gaining power to solve problems, and increased self-control. These positive psychological impacts via more participation in travel have been investigated in previous research and were confirmed by the current study. In the dimension of physical wellness, the importance of the chance to have a natural food intake was recognized by $70 \%$ of participants, and the resulting increased appetite and improved digestion experienced by $26 \%$. Appropriate nutrition and balanced diets are important for maintaining physical condition and wellness [38] and loss of appetite has been shown as a negative indicator of physical health. Feeling natural energy, feeling healthier and increasing body activity and movement were suggested by $40 \%$ to $47 \%$ of participants. Activity and body movement, feeling energy, and feeling healthy are seen as being physical wellness indicators. In the social health dimension, relationship improvement was felt by $51 \%$ of the participants, and more understanding and love for each other, and more opportunity to talk were suggested by $30 \%$ to $38 \%$ of the participants. Social support features, such as intimacy, trust, respect, and self-expression in social relationships, have been shown to be significant indicators of social health.

A positive impact on sustainable health has been found to be gained from general leisure participation, and from particular leisure types or functions; for example, outdoor recreation (park) visits [19,31]. These also have a positive impact on stress [9] and mood regulation [2]. The fact that leisure participation influences human psychological, physical, and social wellness has also been well supported in the therapeutic recreation area [62]. However, the impact of travel has not yet been fully researched with regard to its health effects, or its possible functional role in the achievement of personal health. In this regard, the results of this study are an innovative initiative in the exploration of travel health effects.

The findings of the study present direct and indirect evidence of the contribution that the tourism industry delivers to people who are short of experiencing/encountering natural treasures in well-preserved landscapes and are looking for mental refreshment and abundance by escaping to natural spaces in their daily life in urban areas. In terms of physical and tangible perspectives, healthy food also can be a significant catalyst in that sector of the tourism industry that is involved in health and nature at tourist destinations. Organic food, in-season grown food, free range livestock produce, and natural growing, which are strongly in line with nature and natural mechanisms, are important for tourists. If people make more of natural encounters and appreciate the significance through their travel activities that nature brings to the tourism industry, they will tend to take more interest in natural richness and even watch their dietary habits to gain health benefits. Thus, healthy food is in line with heathy tourism as indicated by the results of the current study.

By awakening this type of holistic travel activity in relation to the health-oriented travel activities in the domestic travel environment they can access easily (without long haul and/or spending excessive money for luxurious activities in mass tourism destinations), the tourism industry can find a sustainable niche and opportunistic area without massive and nature-breaking tourism development.

\section{Conclusions}

\subsection{Theoretic Contribution}

The most significant theoretical outcome of this study is the finding relating to new health-contributing travel items for tourists. In addition, this study is unique and timely as it focuses on domestic tourists who take daily package tour programs and investigates the influences of health-oriented travel elements within these programs. This facet of tour programs has been the least studied although it has been a highly popular type of tourism activity in many countries, particularly in East Asia.

In previous studies, the general hypothesis has been that outdoor activities have positive impacts on physical, intellectual, social, and spiritual health, and positive impacts on subjective $[6,16]$ and 
psychological wellness; but what the specific elements of travel influencing health actually are has not been clearly shown. This study contributes to the further development of the theories regarding the impact of travel on health by identifying specific contributing elements in the psychological, physical and social domains of health. In addition, analysis of the participants' open-ended answers provides extra data expanding on the health-contributing travel aspects. Another theoretical contribution is that whereas most health tourism studies are focused on international tourists, this study is innovative by focusing on the domestic market and tourists in the health tourism field and mounting an insightful investigation into its three main perspectives and its substantial attributes.

\subsection{Practical Implications}

Among leisure activities, the impact of sports and physical activity on human health are generally known from research that has focused on specific leisure activities. One of the important characteristics of travel is leaving a usual residence and moving to another place. Several studies have provided evidence that supports the view that pleasant moods and positive attitudes play an important role in maintaining psychological and physical health, and positive human functioning [63,64]. However, these points have rarely been reviewed with respect to the contribution of travel to a tourist's motivation to undertake health-related tours. As shown in this study, many people experienced good feelings and the lifting of bad moods through travel. Mood enhancement through travel should be explored further, particularly for its positive impact on human health. The findings from this study are useful for developing the health requirements of travelers, a significant step to enhancing the quality of this type of travel service through better product development and enhanced service quality. Many tourism products or programs can add health-related factors and attributes into their products to differentiate and strengthen their attraction to potential tourists. This could contribute to the attraction of daily domestic tourists who wish to escape from their stress-ridden modern life. It also could be more strategic to target those elderly people who have a strong interest in enhancing their health conditions through leisure activities and have sufficient time and financial resources to do so.

\subsection{Limitations and Further Research}

Although this study is pioneering research on the motivations of domestic health tourists, it is not free from limitations. The study targeted the case of domestic tourists taking one-day tours, so the health-contributing travel elements that were identified in this study might not apply to other travel products or may even be enhanced if longer tours are taken. Further research can also be developed to expand and refine the health-contributing elements of travel in more cases and perhaps in other countries. Moreover, consumer understanding and awareness of the impact of travel on their health enhancement could be expanded to increase demand in the travel industry. As this study focuses on the case of Korea, comparative studies with other destinations and products in other countries at a similar development stage in the health tourism industry as Korea would also add value and contribute to better tourism product development. Despite such limitations, the results and implications of this study provide useful information about domestic health tourism in Korea and may assist marketing development in other countries that are facing similar health-related tourism development and marketing issues. From the aesthetic perspective, it would also be interesting to investigate the link between the values put on nature/landscape by the tourist and their feelings of improved health.

Author Contributions: Conceptualization, J.-S.H. and T.J.L.; methodology, J.-S.H.; formal analysis, T.-G.K.; investigation, T.-G.K.; resources, J.-S.H.; data curation, T.J.L.; writing—original draft preparation, J.-S.H.-review and editing, T.J.L.; visualization, T.-G.K.; supervision, T.J.L.; project administration, T.-G.K.; funding acquisition, T.-G.K. All authors have read and agreed to the published version of the manuscript.

Funding: This research was funded by Hallym University in South Korea, grant number HRF-201805-004. 
Conflicts of Interest: The authors declare no conflict of interest. The funders had no role in the design of the study; in the collection, analyses, or interpretation of data; in the writing of the manuscript, or in the decision to publish the results.

\section{References}

1. Dolnicar, S.; Yanamandram, V.; Cliff, K. The contribution of vacations to quality of life. Ann. Tour. Res. 2012, 39, 59-83. [CrossRef]

2. Han, J.-S.; Lee, T.J.; Ryu, K. The promotion of health tourism products for domestic tourists. Int. J. Tour. Res. 2018, 20, 137-146. [CrossRef]

3. Hoheb, C. Wellness Tourism. In The Sage International Encyclopedia of Travel E Tourism; Lowry, L.L., Ed.; Sage: Thousand Oaks, CA, USA, 2017; pp. 1433-1436.

4. Cho, H.; Lee, T.J. Stakeholders in the medical trade: The case of South Korea's networks with China and the United States. Int. J. Tour. Res. 2020. [CrossRef]

5. Cooper, M.; Vafadari, K.; Hieda, M. Current Trends and Emerging Issues in Medical Tourism; IGI Global Press: Hershey, PA, USA, 2015.

6. McCabe, S.; Johnson, S. The happiness factor in tourism: Subjective well-being and social tourism. Annal. Tour. Res. 2013, 41, 42-65. [CrossRef]

7. Yoo, I.Y.; Lee, T.J.; Lee, C.K. Effect of health and wellness values on festival visit motivation. Asia Pac. J. Tour. Res. 2015, 20, 152-170. [CrossRef]

8. Chen, K.H.; Chang, F.H.; Tung, K.X. Measuring wellness-related lifestyles for local tourists in Taiwan. Tour. Anal. 2014, 19, 369-376. [CrossRef]

9. Choi, K.; Meng, B.; Lee, T.J. An investigation into the segmentation of Japanese traditional "Ryokan" hotels using selection attributes. J. Vacat. Mark. 2018, 24, 324-339. [CrossRef]

10. Choi, K.; Lee, T.J.; Kim, H.K. Strategic marketing development of hospitals participating in medical tourism: A case of South Korea. Tour. Anal. 2015, 20, 129-136. [CrossRef]

11. Yu, J.; Lee, T.J.; Noh, H. Characteristics of a medical tourism industry: The case of South Korea. J. Travel Tour. Market. 2011, 28, 856-872. [CrossRef]

12. Kim, S.S.; Lee, J.; Jung, J. Assessment of medical tourism development in Korea for the achievement of competitive advantages. Asia Pac. J. Tour. Res. 2013, 18, 421-445. [CrossRef]

13. Lin, C.H. Determinants of revisit intention to a hot springs destination: Evidence from Taiwan. Asia Pac. J. Tour. Res. 2013, 18, 183-204. [CrossRef]

14. Chang, L. The relationship between nature-based tourism and autonomic nervous system function among older adults. J. Travel Med. 2014, 21, 159-162. [CrossRef] [PubMed]

15. Erfurt-Cooper, P.; Cooper, M. Health \& Wellness Spa Tourism, Aspects of Tourism Series; Channel View Press: London, UK, 2009.

16. Gilbert, D.; Abdullah, J. Holiday taking and the sense of well-being. Ann. Tour. Res. 2004, 31, $103-157$. [CrossRef]

17. Hjalagera, A.M.; Flagestad, A. Innovations in well-being tourism in the Nordic countries. Curr. Issues Tour. 2012, 15, 725-740. [CrossRef]

18. Lee, C.F.; Ou, W.M.; Huang, H.I. A study of destination attractiveness through domestic visitors' perspectives: The case of Taiwan's hot springs tourism sector. Asia Pac. J. Tour. Res. 2009, 14, 17-38. [CrossRef]

19. Orsega-Smith, E.; Mowen, A.J.; Payne, L.L.; Godbey, G. The interaction of stress and park use on psycho-physiological health in older adults. J. Leis. Res. 2004, 36, 232-256. [CrossRef]

20. Hieda, M. The Psychology of Medical Tourism. In Current Issues and Emerging Trends in Medical Tourism; Cooper, M., Vafadari, K., Hieda, M., Eds.; IGI Global: New York, NY, USA, 2015; pp. 44-57.

21. Kim, H.J.; Lee, T.J.; Ko, T.G. A comparative study of health tourism seekers and non-seekers' satisfaction and subjective well-being evaluation: The case of Japanese and Korean tourists. J. Travel Tour. Market. 2016, 33, 742-756. [CrossRef]

22. Walker, T.; Lee, T.J. Visitor and resident perceptions of the slow city movement: The case of Japan. Int. J. Tour. Sci. 2019, 19, 112-127. [CrossRef]

23. Güzel, O.; Sahin, I.; Ryan, C. Push-motivation-based emotional arousal: A research study in a coastal destination. J. Destin. Market. Manag. 2020, 16, 100428. [CrossRef] 
24. Strauss-Blasche, G.; Reithofer, B.; Schobersberger, W.; Ekmekcioglu, C.; Wolfgang, M. Effect of vacation on health: Moderating factors of vacation outcome. J. Travel Med. 2005, 12, 94-101. [CrossRef]

25. Sopha, C.; Jittithavorn, C.; Lee, T.J. Cooperation in health and wellness tourism connectivity between Thailand and Malaysia. Int. J. Tour. Sci. 2019, 19, 248-257. [CrossRef]

26. Smith, M.; Puczko, L. Health and Wellness Tourism; Butterworth-Heinemann: London, UK, 2010.

27. Voigt, C.; Brown, G.; Howat, G. Wellness tourists: In search of transformation. Tour. Rev. 2011, 66, 16-30. [CrossRef]

28. Finnicum, P.; Zeiger, J.B. Tourism and wellness: A natural alliance in a nature state. Parks Recreat. 1996, 31, 84-95.

29. Bookman, M.Z.; Bookman, K.R. Medical Tourism in Developing Countries; Palgrave Macmillan: New York, NY, USA, 2007.

30. Laesser, C. Health travel motivation and activities: Insights from a mature market-Switzerland. Tour. Rev. 2011, 66, 83-89. [CrossRef]

31. Lim, Y.J.; Kim, H.K.; Lee, T.J. Visitor motivational factors and level of satisfaction in wellness tourism: Comparison between first-time visitors and repeat visitors. Asia Pac. J. Tour. Res. 2016, 21, 137-156. [CrossRef]

32. Brannon, L.; Feist, J. Health Psychology: An Introduction to Behavior and Health, 5th ed.; Thomson: London, UK, 2004.

33. Sanderson, C.A. Health Psychology; John Wiley \& Sons: Hoboken, NJ, USA, 2004.

34. McGinnis, J.M.; Foege, W.H. Actual causes of death in the United States. J. Am. Med. Assoc. 1993, 270, 2207-2212. [CrossRef]

35. World Health Organization. Executive Board, 101st Session, Geneva, 19-27 January 1998: Summary Records; World Health Organization: Geneva, Switzerland, 1998.

36. Wellness Tourism Worldwide. 4WR: Wellness for Whom, Where and What? Wellness Tourism 2020 Full Report; Xellum: Budapest, Hungary, 2011.

37. Moon, S.; Choi, M. Health Administration, 4th ed.; Bomungak: Seoul, Korea, 2011.

38. Naidoo, J.; Wills, J. Foundations for Health Promotion, 3rd ed.; Elsevier Health Sciences: London, UK, 2009.

39. Hills, P.; Argyle, M. The Oxford Happiness Questionnaire: A compact scale for the measurements of psychological well-being. Personal. Individ. Differ. 2002, 33, 1073-1082. [CrossRef]

40. Lee, K.H.; Lee, T.J. Opportunities and issues in the health tourism industry: Deep sea water development in Taiwan. Tour. Anal. 2015, 20, 419-424. [CrossRef]

41. Bradburn, N.M. The Structure of Psychological Well-Being; Aldine: Chicago, IL, USA, 1969.

42. Lawton, M.P. The dimension of moral. In Research Planning and Action for the Elderly: The Power and Potential of Social Science; Kent, D.P., Kasternbaum, R., Sherwood, S., Eds.; Behavioral Publications: New York, NY, USA, 1972; pp. 144-165.

43. Goldberg, D.P. The Detection of Psychiatric Illness by Questionnaire; Oxford University Press: London, UK, 1972.

44. Fazio, A.F. A concurrent validational study of the NCHS General Well-being Schedule. Vital Health Stat. 1977, 73, 1-53.

45. Veit, C.T.; Ware, J.E., Jr. The structure of psychological distress and well-being in general populations. J. Consult. Clin. Psychol. 1983, 51, 730-742. [CrossRef]

46. Keyes, C.L.M. Mental illness and/or mental health? Investigating axioms of the complete state model of health. J. Consult. Clin. Psychol. 2005, 73, 539-548. [CrossRef] [PubMed]

47. Ryff, C.D.; Singer, B. Psychological well-being: Meaning, measurement, and implications for psychotherapy research. Psychother. Psychosom. 1996, 65, 14-23. [CrossRef] [PubMed]

48. Macmillan, A.M. The health opinion survey: Technique for estimating prevalence of psychoneurotic and related types of disorder in communities. Psychol. Rep. 1957, 3, 325-329. [CrossRef]

49. Ware, J.E.; Kosinski, M. Interpreting SF-36 summary health measures: A response. Qual. Life Res. 2001, 10, 405-413. [CrossRef]

50. Pfeffer, R.I.; Kurosaki, T.T.; Harrah, C.H., Jr.; Chance, J.M.; Filos, S. Measurement of functional activities in older adults in the community. J. Gerontol. 1982, 37, 323-329. [CrossRef] [PubMed]

51. Sarason, I.G.; Levine, H.M.; Basham, R.B.; Sarason, B.R. Assessing social support: The social support questionnaire. J. Personal. Soc. Psychol. 1983, 44, 127-139. [CrossRef]

52. Chou, K. Assessing Chinese adolescents' social support: The multidimensional scale of perceived social support. Personal. Individ. Differ. 2000, 28, 299-307. [CrossRef] 
53. McFarlane, A.H.; Neale, K.A.; Norman, G.R.; Roy, R.G.; Streiner, D.L. Methodological issues in developing a scale to measure social support. Schizophr. Bull. 1981, 7, 90-100. [CrossRef]

54. Billings, A.G.; Moos, R.H. Social support and functioning among community and clinical groups: A panel model. J. Behav. Med. 1982, 5, 296-311. [CrossRef]

55. Gianfredi, V.; Albano, L.; Basnyat, B.; Ferrara, P. Does age have an impact on acute mountain sickness? A systematic review. J. Travel Med. 2020. [CrossRef]

56. Jo, S. The study of tourist stress on overseas traveling. J. Glob. Acad. Market. Sci. 2006, 16, $27-43$.

57. Swarbrooke, J.; Horner, S. Consumer Behavior in Tourism; Butterworth-Heinemann: Oxford, UK, 2007.

58. Gan, L.L.; Frederick, J.R. Medical tourism facilitators: Patterns of service differentiation. J. Vacat. Market. 2011, 17, 165-183. [CrossRef]

59. Rodrigues, A.; Kastenholz, E.; Rodrigues, A. Hiking as a wellness activity: An exploratory study of hiking tourists in Portugal applied to a rural tourism project. J. Vacat. Market. 2010, 16, 331-343. [CrossRef]

60. Rest in Korea. 2013. Available online: http://www.restinkorea.com/default_eng.asp (accessed on 10 July 2013).

61. Veal, A.J. Research Methods for Leisure and Tourism: A Practical Guide, 3rd ed.; Pearson Education: Edinburgh Gate, UK, 2006.

62. Austin, D.R. Therapeutic Recreation: Processes and Techniques, 6th ed.; Sagamore: Champaign, IL, USA, 2009.

63. Fredrickson, B.L.; Losada, M.F. Positive affect and the complex dynamics of human flourishing. Am. Psychol. 2005, 60, 678-686. [CrossRef] [PubMed]

64. Fredrickson, B.L.; Mancuso, R.A.; Branigan, C.; Tugade, M. The undoing effect of positive emotions. Motiv. Emot. 2000, 24, 237-258. [CrossRef] [PubMed]

(C) 2020 by the authors. Licensee MDPI, Basel, Switzerland. This article is an open access article distributed under the terms and conditions of the Creative Commons Attribution (CC BY) license (http://creativecommons.org/licenses/by/4.0/). 